\title{
Smells, Things, Sounds: Signs of the Past in the Works by A.Astvatsaturov
}

\author{
Giulia Marcucci* \\ University for Foreigners of Siena. International University \\ 27/28 Piazza Carlo Rosselli, Siena, 53100, Italy
}

Received 10.01.2017, received in revised form 12.02.2018, accepted 07.03.2018

\begin{abstract}
A new wave of Russian writers began to publish their works at the turn of the 20th-21st century. Although it is not possible to speak of a homogeneous trend, in their novels and short stories we note a revival of traditional narrative forms and a renewed interest in psychology and life events. Among such authors, we find a St. Petersburg writer Andrei Astvatsaturov, who explores St. Petersburg's present in close connection with Leningrad's past through the memories of his main character. In the spotlight of his first two books, "People in the Nude" and "Skunskamera", we do not find any simple objects but we find, using the terminology of Yu.M. Lotman, "signs of time". In the present contribution, the linguistic and semiotic analysis of some examples from Astvatsaturov's books focusing on things and sounds from the Soviet past indicates, in line with S. Boym's definition of reflective nostalgia, that the world of childhood, not at all devoid of blame and weakness, and treated in an ironic Chekhovian manner, is lost and partially idealized because of the gloom of life in the present. A comparison with the film "Pioneer Heroes" by Natalia Kudriashova, where similar "things" are showed through iconic signs of the cinema, is also mentioned.
\end{abstract}

Keywords: restorative nostalgia, reflective nostalgia, Soviet past, contemporary Russian literature, signs.

DOI: $10.17516 / 1997-1370-0233$.

Research area: philology.

\section{Introduction}

In the 2000-s, there appeared a constellation of young writers born in the 70 -s - early 80 -s and brought up in the sociocultural context, dramatically different from the post-Soviet society. The debut of these writers, such as Z. Prilepin, M. Elizarov, A. Snegirev, A. Ganieva, I. Abuziarov, was shaped by a number of factors: the establishment of new publishing houses at the turn of the $90-\mathrm{s}$, thirsty for new names and tired of "contemporary classics"; emergency of new literature awards besides the existing ones; organization of the Young Writers' Forum in Lipki (Moscow Oblast), created in the year 2001 with the assistance of the leading literary magazines, famous prose writers and literary critics (Kovtun, 2016: 60; Cherniak, 2016: 319). In the year 2016, announced to be the Russian Year of Literature, this unique event was visited by writers from 77 regions of the country. They came together to

(C) Siberian Federal University. All rights reserved

* Corresponding author E-mail address: nkovtun@mail.ru 
attend seminars, round tables and workshops in various literary genres, discussed a huge number of texts, both written by themselves and other authors, received highly relevant comments and publication recommendations from writer O. Novikova.

Besides these aspects, that, doubtlessly, contributed to the refreshment of literary world, it is worthwhile noticing that in the early $21^{\text {st }}$ century, the writer's role in the society was not the only one to be changed; the reader, tired of the post-Soviet discourse with the never-ending ironic hints on the Soviet past, overwhelming quotes and "playing classics", not always clear to the audience, reviewed his roadmap. For this reason, as M. Cherniak claims, "The pivot idea of the new generation was the so-called new realism" (Cherniak, 2016: 320). The writers of the 2000-s are especially interested in the documentary description of the contemporary world in exquisite detail. They are looking at the Soviet past through different eyes, with growing nostalgia and even admiration, often associating the idea of the "Soviet" with the concept of "home". Their stories are centred around simple people, their everyday life and problems (it is enough to mention the book by R. Senchin Flood Zone, 2015), intellectuals, not the so-called "new Russians" (not a new phenomenon any more), not the oligarchs and businessmen the mass and glamorous literature focuses on.

More attention is being paid to the stories that unwind in such locations as Dagestan, Tatarstan, Armenia, Chechnya (let us recall, at least, the books by A. Ganieva, N. Abgarian, G. Yakhina, G. Sadullaev). This fact points to the rising tide of interest to the motives, absent since the collapse of the Soviet Union, remarks L. Ulitskaia in her Introduction to the novel Zuleikha Opens Her Eyes (2015), and adds, that previously there also was a great constellation of
Russian-speaking writers, such as Fazil Iskander, Chingiz Aytmatov, Anatoly Kim etc., belonging to other ethnicities, whose texts united folklore motives and profound love for the motherland (Ulitskaia, 2015: 5).

According to A. Ganieva, sceptic about the frequent use of the word "new" to describe the writers who became popular in the 2000 -s, the new realism term absorbs some traits of postmodernism, such as the concept of the world created from chaos, realism and romanticism "with the mind set on the existential dead end" (Ganieva, 2010: 140). New realism does not have to be understood as a homogenous stream of a certain number of authors; it is a general idea of the world described through various expressive techniques. For real, even if all the writers of the 2000-s are known for their interest for reality, traditions, autobiography and (neo)sentimentalism, we cannot say that all of them stick to one and the same literary "trend". In light of this idea, let us focus on the works by a St. Petersburg writer A. Astvatsaturov, the author of three novels: "People in the Nude" (2010), "Skunskamera" (2011) and "Autumn in the Pockets" (2015), in order to reveal the main literary techniques that can be observed in the first two novels as parts of an incomplete trilogy. The reason for selecting this writer is the dialectic opposition of the past and present realities that underlie the mentioned two novels.

\section{Problem setting}

The "four eyes" character of the first two novels of the St. Petersburg writer travels from the real world of the present, where he, just like A. Astvatsaturov himself, is a docent at St. Petersburg University, to the world of his memories, to the past, where he was a boy living in Leningrad with all its smells, sounds, and, particularly, "things", forming the way of 
life of that time. By the way of life, following Yu.M.Lotman, we understand "[...] common flow of life in its real and practical forms; way of life is comprised of the things surrounding us, our habits and everyday behaviour. It surrounds us like air, but, just like air, it is noticed only when it is spoiled or deficit" (Lotman, 1994: 10). The analysis of "things" is directly connected to the analysis of rituals, everyday habits, that, for A. Astvatsaturov, trace their root to the turn of the 70 -s and 80 -s of the $20^{\text {th }}$ century.

His prose, distinctive for rich descriptions of the "everyday trifles" (material and tangible ones, and, particularly, smells), may be compared to the contemplations of S. Boym, an immigrant to the USA, of nostalgia and nostalgic story, which, in her opinion, is capable of reproducing sounds, smells and details of the lost paradise, unlike the people in the motherland, who have never been aware of them (Boym, 2003: 3). The first "official" victims of nostalgia are the people living far away from home. This term traces its origin to the Swiss doctor Johannes Hofer, who, in the year 1688, described a pathology with physical and psychic symptoms previously treated with opium, leeches and other methods, but still the best remedy of it was to return to the homeland. According to Boym, nostalgia was often associated with melancholy and hypochondria, where melancholy was assigned to monks and philosophers, intellectuals, who had always suffered of something similar to Hamlet's "to be or not to be"; nostalgia, in its turn, was the lot of soldiers and sailors, as well as peasants moving to the city. This pathology, however, was caused not only by the change of residence; it was also determined by the perception of time, which at the turn of the $17^{\text {th }}-19^{\text {th }}$ centuries began to be associated with money.

Thus, we may conclude that the categories of place, time, and progress became the fundamental factors of the nostalgia disease, while its symptoms were the aspiration for the past and the fear of the future. We cannot but mention that in the $18^{\text {th }}$ century those were not doctors, but poets and philosophers, who dealt with nostalgia, turning the pathology into an attribute of sensitivity and love for the motherland. It was not treated, but, on the opposite, encouraged. However, the diachronic analysis lies beyond the framework of this research focused on the analysis of certain parts of the two novels by A. Astvatsaturov centred around the childhood of the protagonist from the linguistic and semiotic points of view. Our analysis is based on the distinction between restorative and reflecting nostalgia suggested by Boym. In the first case, the past, described without any features of decay, is valuable for the present, its centre, the nostos. In the latterthe centre is algia, the details and fragments of memories of the historical and individual past. Reflective nostalgia reveals that "longing and critical thinking are not opposed to one another, just as affective memories do not absolve one from compassion, judgement, or critical reflection" (Boym, 2013). That means that the narration based on the second type is ironic and fragmentary, while the restorative nostalgia is "suffocating serious". Italian specialist in Slavic studies L. Salmon supposes that reflective nostalgia expresses a mental condition or a style of sensation close to the English lexeme melancholy or Russian lexemes меланхолия (defined by V.Dal as "thoughtful yearning") and тоска, which, followed with the postposition no, indicates nostalgia for someone or something (Salmon, 2015: 22-23). Relying on these definitions, we suggest, based on the selected parts of the two novels, to determine which type of nostalgia reveals itself in the memories described by the author. 


\section{Objects versus things: childhood as paradise}

Let us study one of the first short stories of "Skunskamera" novel titled "The Golden Ring". It begins with a description of a Soviet beer stand:

You may have forgotten, but in the Soviet time, beer stands used to work temperamentally just like everything else, just like factories, stores, tailors or research institutions. The developed socialism society was the society of a performance, moronic to a great extent, not an affluent society at all. And there was not enough beer for everyone. Or, to be more precise, there was enough beer, but not everywhere and not every time (Astvatsaturov, 2011: 10).

In this paragraph the protagonist defines the Soviet society of the mid-60-s - mid-80-s as a society of performance, specialized as "moronic": the subject matter is the society where everything works temperamentally and which could not be described as affluent. The exception was the beer stands, proceeds the protagonist, standing one in front of another on the square called the Muzhestva Square where he lived. It was an exception because if one of the stands ran out of beer, it could be found in another. This trip back and forth was a way to find lots of acquaintances, even if they lasted for a day. The modern situation is described only at the end of the story:

Every time I bring a bottle of cold beer or a big frosty glass with gold-coloured drink to my lips, the strong smell of brewery hits my nostrils. I bitterly realise that all that joyful beer world is gone forever. The golden rings that have lost their power over people are gone with the furious lava of the 1990-s. The beer Nibelungs, orcs, and goblins have been driven out of sight to the stuffy chambers of bars and clubs. They are still there, sitting, smoking, sullenly drinking their beers under the lidless eye of the broad-shouldered bouncer. No more trips, no more adventures, merits or feats, no more heart-to-heart conversations. All talks drown in the roaring music (Astvatsaturov, 2011: 11-12; hereinafter, italics by J.M.)

The bitter realization (I bitterly realize) is opposed to the spontaneity and joy of those unfortunately gone, erased by the 1990-s, as an inexorable stream of lava: a metaphor presenting the Soviet Union as a huge erupted volcano, making the post-apocalyptic scenario come true. The open-air beer stands have been replaced with stuffy and uniform indoor bars: the noun chamber and the adjective stuffy, the metaphors of Nibelungs, orcs and goblins referring to the bar visitors create a claustrophobic image of a prison, raising the question of the freedom lost. The two conclusive phrases reflect the state of complete isolation as a result of the changes described above: the new world of bars with broad-shouldered bouncers is an isolated, artificial world, that lacks the spirit of adventure, heroism and sincerity. At the end, the notion of "merit" is opposed to roaring music, drowning any natural conversation.

The motive of beer appears in one of the following short stories titled "Smells of Memories". In this stylistic imitation of Marcel Proust, the smell of this drink evokes several memories and visions in the "warm depth of the memory" of the main character: those are houses, smiling women, and, again, beer stands. This short time travel is abruptly interrupted with the present, coloured in grey tones. The memories do not appear any more, buried under the clatter of advertising billboards the main character sees from the window of his flat on the eighth floor of the apartment block on Muzhestva Square, which he, though calls a knackery, does not want 
to leave, because the outer world is absolutely of no interest for him.

Besides the smells they bring to life, the memories of the past described in "Skunskamera" also contain some sounds. For example, in the short story titled "Street" the main character is looking out from the window, observing the traffic of cars that, he feels, have dramatically changed. When he was little, looking at cars he felt scared and defenceless, now, in an instant ("in a moment", Astvatsaturov, 2011: 25), they turned so elegant, slim and reliable, even "obedient, smart, understanding” (Astvatsaturov, 2011: 26). Only the trams compared to enormous lizards desperate to drop their heavy metal shells, managed to resist these changes, retaining their rattle in the way it used to be. At the end of the story, this noise feels good for the main character, because it remains something, or a sign of something left from the past:

It feels nice that some things or at least the signs of the previous years are still there. Just like the sounds of the street, extruding the longforgotten images from the past (Astvatsaturov, 2011: 26).

The students' dormitory building, where African students lived, was just as noisy: that was the period of the "great friendship of the nations". Today, the building has "drowned in gloomy lethargy" (Astvatsaturov, 2011: 26), and its sterility is emphasized with the attribute "standard" and multiple repetition of the adjective "same", describing the same desks and chairs for the tired, bored and stupid white students, future computer science geniuses (Astvatsaturov, 2011: 27). Not a whisper of the slogans everyone used to believe is there - or, at least, that is what the main character feels ("as it seemed to me", "as I wanted to believe", Astvatsaturov, 2011: 27-28), just like not a whisper of that brotherly care and friendship the Africans enjoyed in the 1970-s was there anymore. Like "Golden Ring" and many other stories of the two novels by Astvatsaturov, this story emphases the isolation of society, its incapability for socialization, the loss of direction and faith, which makes up everything it could be proud of, and its sterility and automatism.

The picture of the past and the childhood shown by "Skunskamera", as it has been mentioned in the Introduction, is directly connected to the everyday way of life, the ordinary things and objects. We can feel it in the description of a grocery store on Thorez Avenue and its departments, especially the butchery and the butcher himself, nicknamed Osya Brodsky by the protagonist's parents for the resemblance to the poet who was forced to leave the country for having been accused of parasitism in 1972, i.e. a little earlier than the events described in the story. This memory gives the author a reason to state, that now children can be curious, while in the Soviet time this curiosity was truly dangerous: due to their childish frankness, they could ask questions unthinkable at that time, such as of the KGB or real Osya Brodsky, making their parents hush them down and tell them not to interfere into adult conversations. The references to the gap between the worlds of adults and children, with the latter dominated by taboos, restrictions and prohibitions, are typical for these two novels, explaining one of the reasons for loneliness the protagonist of "People in the Nude" and "Skunskamera" mentions so frequently. But now we would like to draw your attention to the image of childhood, mythical from the point of view of the present, but, on the other hand, not completely transparent, which will be explained in the next parts of the research.

In the short stories titled Juice Section and Tsarevich Ivan and Bread, the protagonist recalls large cones where the juice was poured right from 
the jars. The cones were at the shop where he and his mother used to drop in from time to time.

At the tips of the cones, there were little taps, from which the shop assistant poured the juice into one and the same glass, one for all, having rinsed it quickly, or "having washed it first" (Astvatsaturov, 2011: 74). In any case, hygiene was out of the question; what mattered was the illusion of hygiene, also noticed by G. Piretto in La vita privata degli oggetti sovietici (Piretto, 2012: 58-59) and confirmed by "red lumps" in the salt cellar for the tomato juice lovers, described after the pleasant memory of the juice cone. The red lumps in white salt proved the negligence of the aluminium spoon, attached for salting the juice. But all those common things were valuable for the little child. He felt sorry when they were "suddenly" replaced with plastic machines, "stupid" and "awkward".

I was explained that the plastic chambers are new and improved equipment, where juice does not stagnate. But I still missed the old glass cones with their little taps. I felt like I had been deprived of something important, replaced with a fraud (Astvatsaturov, 2011: 74-75).

The verb "feel like" introduces the sensation of a forced abandonment of something important and authentic, while the new thing is an artefact. For this reason, right after this contemplation, the author prefers to continue the "trip" with his protagonist to the next section of the store, the bread section he loved most of all.

The central concept of bread description is its "warm" smell the protagonist perceived "with pleasure". The memory of bread, understood as an object in a great diversity of forms ("the smell of tightly packed baguettes, known as 'capital baguettes', 'city baguettes' and 'long loafs', round rye bread, bubliks, puff pastries and sweet buns", Astvatsaturov, 2011: 75), transforms into a different understanding of bread as a thing that evokes emotions. Once the bread served for snack at the kindergarten was damp (the protagonist ironically remarks that though it is common to believe now that bread in the USSR was special, it was not, and sometimes even a condom could be found in the dough) and the children began to make guns and photo cameras out of the bread, until their strict teacher came in. It took her a moment to settle everything; she reminded the children that she survived the Blockade only due to the small portions of bread distributed every day, and that real people of Leningrad had to treat bread with respect. She said, the ones who don't, will grow up into enemies of the nation and "real fascists". Compared to modern pastry, "edible, always fresh, sweet resin" (Astvatsaturov, 2011: 84) the memory of the kind man with moustache and a blue apron standing behind the counter looks especially bright; by any bread stand, there was a special fork for feeling the bread texture.

\section{Faecal motive: childhood as the world of fear}

The bread and strict teacher episode enhanced the contrast in the image of childhood presented in the novel. Actually, we see an adult man, looking back to his past and reconstructing these years as an original, authentic world. This sensation grows stronger in the "Jew's Father" episode. It tells a story from the childhood of the protagonist's father spent in a communal apartment, when he was bullied by other children for being a Jew. Today, the author remarks, there are no more yards attached to the houses with communal apartments; they have transformed into parking lots for luxurious cars. These streets are full of engine roar, they bear different names, and the former hooligans have been replaced with good-mannered managers.

In the early 1990-s, Mayorov Avenue was renamed into Voznesensky. The communal 
apartments with one toilet for twenty rooms were separated. Their former ardent residents were sent to the dormitory suburbs. Now the place is sullen and empty. The yards where street gangs used to gather, turned into cosy parking lots for expensive cars. The quiet and suspicious streets scary even during daytime, now smile with joyful advertising boards and the roar of engines. The new residents, wealthy managers, have only good intentions: they never misbehave or bully anyone (Astvatsaturov, 2011: 104-105).

Comfort and wealth have deprived these places of their individuality, which is indicated with the key words sullen and empty. On the other hand, as it has been mentioned above, the childhood described by the author reflects the scary reality of that historical period. For example, fear and loneliness are the two feelings accompanying the compulsory medical examination procedure school children had to go through on September 1, and its climax, a gamma globulin injection. In the short stories "People in the Nude" and "Gamma Globulina" from "People in the Nude", this word is highlighted by italics (typical for many other contemporary writers, such as E.Popov). The episode systematically reproduces all stages of the procedure living in the memory of the adult person, and this description evokes feelings so strong, that they are almost physical. Let us read it:

Every year on September 1, we were exposed to a "medical examination". The examination always finished with a procedure humiliating for every child. The nurse made each one lie down on the couch, face down. Then she pulled the child's underpants down and injected "gamma globulina" into his butt. It was not just painful. It was painful and shameful at the same time. [...] You were lying face down, with your butt looking up, and your classmates, mobbing around the door, were staring at you. You were absolutely naked (the underpants pulled down to the knees did not count), defenceless and lonely. The anticipation of the injection, while the nurse was filling her syringe, lasted forever. You could feel the eyes of your class mates on yourself, on your naked and shameful butt.

Especially those of the girls.

GAMMA GLOBULINA. When I heard this combination of words, my loneliness felt especially intolerable (Astvatsaturov, 2010: 34-35).

A similar procedure hung over college students as well, which is proven by "Urine Test" story, which tells about the adventures of the protagonist's friend, Oleg Tabonin, who studied at Tartu in the eighties. To be admitted to the next year of study, it was required to go through a medical examination and do a urine test. Tabonin decided to bring his material in a mayonnaise jar. As the lid wouldn't close and it was not possible to put the jar in the bag, Tabonin wrapped it in a newspaper to conceal the content, but the rain on the mission day disrupted the plan. But Oleg did not give up: next day, he collected the material in the same vessel and had the foresight to wrap it in a plastic bag. But he failed again: Yu.M. Lotman who lived in the same building where the clinic was, invited the hero for lunch, and Oleg had to leave the jar in the garbage can by the door; when he returned, it was gone. In this "anecdote" we witness one of the distinctive features of prose by Astvatsaturov, who knew how to tell a serious story with a humorous effect by combining opposite concepts (remining of Chekhovian poetics). Thus, in a story of several pages, digressing to anecdotes from the lives of his friends and bringing different categories together, the author presents the picture of the late Soviet period in a humorous manner. For example, in one of the paragraphs we read: "In the developed socialism era it worked this way: 
once you do your urine test, the big world opens to you. If not, cope with it" (Astvatsaturov, 2010: 64).

\section{When artistic images are supplied by cinema: Pioneer Heroes}

The motive of gamma globulin, injected to schoolchildren, and the urine test draws a parallel between the text by Astvatsaturov and "Pioneer Heroes" movie by Natalya Kudriashova (2015). The story referred to as autobiographic unwinds in two dimensions. The main characters, three friends named Sergeev, Olga, and Katya, live in contemporary Moscow, but, despite their professional success, suffer a personal hell in their psychological life. They have known each other since childhood they spent in province in the eighties; it is the second dimension of time and space, the episodes of which are integrated into the narration of the present to explain the reasons of Olga's panic attacks, Sergeev's workaholism and rejection of a girl desperately in love with him, Katya's psychological problems and personal life disorders. We should not underestimate that, being the director and the screenplay writer, having clearly stated the autobiographic character of her work, Natalya Kudriashova plays the role of Olga herself. It appears important to analyse several episodes. The frame focuses on several children playing during break, and only little Olga is thoughtful. When the teacher, a sullen, strongly built woman, comes in, everyone falls silent and stands up to greet her. She commands children to sit down, and the pioneers immediately obey. The long shot encompasses the whole classroom; on the wall, there are banners with portraits of pioneer heroes and the slogan, "Little Octobrist, follow your way to become a Pioneer one day". To the lordly question, "Have you brought it?" all the children chorus "Yes". Hesitant and bored, looking into the window, the teacher asks the children to take out the "matchboxes" and put them on the side of their desks. The children giggle, but it is interrupted with the abrupt: "What is the laugh about?" Automatically, the teacher asks: "Have you written your names on them?" and then comes the nurse and collects the matchboxes. At the last desk, Olga and Katya are sitting. Olga says she forgot to bring her matchbox, and the teacher demands her record book. The shot of the girl's face is followed by the shot focused on the record book page with a statement: "Bring faeces in a matchbox urgently".

Olga and Katya run to the toilet, and the first one confesses that she feels very ashamed, but she "cannot do it". Katya asks for her matchbox; Olga notices that it is a fraud, but Katya gives her “Octobrist's word" that she wouldn't tell anyone. Katya disappears behind the toilet door, and Olga is waiting for her outside, motionlessly. The episode finishes with a friendly embrace. In the next episode, we see Olga at an appointment with her psychologist, confessing that that shit has become, to a certain extent, a theme of her life.

For a foreign spectator, the function of the matchbox is not clear until the statement of the teacher in the record book appears, provided that the movie has subtitles. However, for a Russian, this thing is a symbol of the epoch. As Yu.M. Lotman wrote about "Chapaev" movie and the Maxim gun: "For a person from the epoch and the civilization unfamiliar with this object, the frame looks mysterious. [...] The gun is not only a thing, it belongs to a certain epoch, acting as a symbol of this epoch" (Lotman, 1998: 321; italics by J.M.).

The authoritarianism and indifference of the teacher on one hand, and fear, shame, loneliness of Olga on the other, are the feelings translated and opposed to each other in this narration. And though real friendship of the two girls helps them cope with all these problems, the events of the 
childhood turn to be a traumatic experience affecting the adult lives of Olga and Katya.

The memories of the teacher from the described episode bring us back to the text by Astvatsaturov. The author speaks of several situations that happened during his school life, draws portraits of his teachers, principals, professors. Thus, the second short story of "People in the Nude" - "First Teachers" memorialize the images of Valentina Stepanovna and Galina Pavlovna: "Valentina Stepanovna, our first teacher, is a woman of non-identifiable age in a blue crimplene dress. She is looking to the camera didactically and reproachingly. There is a big mole on her right cheek" (Astvatsaturov, 2010: 7). Further: "The "tulip" hairstyle a la 50$\mathrm{s}$, reminding of a huge fig, furiously rocked on her head". Of Galina Pavlovna, he writes: "A skinny old lady. Her face reminded me of a polar owl. I saw one on the TV, in "Animal World" programme. On the tip of her nose, eye glasses in a thin golden rim where cautiously blinking; perhaps, it was a present of someone's grateful parents" (Astvatsaturov, 2010: 8). Both these women are the picture of harshness; due to the few, but bright details in the clothes and faces, appealing to the world of animals, their images are easily visualized.

Another eloquent portrait in the gallery of teachers, is the one presented in the short story "Comedy Del Arte" (2016), the portrait of the Deputy Principle nicknamed Artemon. It is another intertextual reference to world literature, cinema and music, the prose of Astvatsaturov is rich in; the hairstyle becomes a base for being compared with a poodle ("an elderly woman with grey poodle-like hair"). The image is detailed through the emphases on the voice ("capricious metallic voice, she uttered it in an icy tone", when she is addressing her students, looking into the window. Moreover, the author draws a parallel with an evil step-mother from fairy-tales.
Interestingly, in the texts of Astvatsaturov a great role is played by dialogues. The witty remarks of the characters are the underlying component in the reconstruction of the atmosphere, the ambience of this or that situation. In the short story titled "Bus Tour" from "Skunskamera" the entire ironic context associated with the figure of Valentina "Stepanna" is formed through accentuation of verbs of volition ("commanded Valentina Stepanovna; ordered Valentina Stepanna; Valentina Stepanna was irritated"). The combination of all these categories of the heard and the observed, as I.A.Martyanova lists among the essential components of a screenplay (Martyanova, 2002), make the texts of Astvatsaturov sound dynamic and audio-visual. The movie by Kudriashova, explicating the entwining visual and verbal signs, to our mind, enables a foreign recipient to visualize the images formed in the process of reading of these two novels more vividly. Besides, the movie "Pioneer Heroes" also begins with a portrait of a teacher, this time, a teacher of music: a skinny woman with eye glasses, a high bun, a harsh male voice and a piercing sight. Her manner of speech is distinguished with frequent repetitions intended to hammer each word deep in the consciousness of children. When little Sergeev singing the leading part rebels and steps forward to say he does not want to sing anymore, she orders him to come out in the centre and announce it to his classmates. "Speak up Sergeev, let everyone hear you. Let everyone know that you are letting them down without any reason. That you do not care that yesterday your mother cried in my office. That you do not feel sorry for your parents or your classmates. That you do not care about the collective".

\section{Conclusion}

The transition from the Soviet world to the contemporary, post-Soviet one, was so 
abrupt and sudden that it left nothing but the feeling of frustration about the today, cold, empty, disappointing to the character of the novels "Skunskamera" and "People in the Nude". The mythic West no one hardly knew anything until the nineties, as Boym suggests, the one imagined to be the ideal world where everyone was dreaming to escape from the Soviet reality, turned out to be not that perfect; and now, only in our memories can we return to the real motherland that was gone together with the childhood, the time when relations between people, just like relations between people and "things", were simple and deep, even though they also had their flaws. The latter are presented by Astvatsaturov ironically, unlike the sullen tone of "Pioneer Heroes". Thus, today's atmosphere of the suffocating, isolated, sterilized, monotonous space is, as a rule, articulated in dark colours; but it is the fact that maintains the connection to the past, makes us hold on to the pieces of the broken time, bringing back the images, sounds, things, objects, that in the temporal distance become clearer and more valuable. In other words, we see the nostalreal, the term introduced by Ivanova for the indication of a stylistic hybrid, or, a stylistic Centaurus: the border between the Soviet and the post-Soviet aesthetics (Ivanova, 2002).

We may therefore conclude, that, though the texts by Astvatsaturov are associated with the post-Modern aesthetics due to the quotation and intertextuality techniques, the writer rejects the "turn from satire to elegy", as Carpi calls it in a wider context of the second millennium literature (Carpi, 2016: 320). It articulates the nostalgia for the past that is now gone, that is impossible to reconstruct otherwise but from the little broken pieces, reproducing the associative mechanisms of the memory and creating the "bits of scraps", or "scarps of bits" (Astvatsaturov, 2010: 144).

\section{References}

Astvatsaturov, A. (2016). Komediia del Arte [Comedy del Arte], In: Znamia, 6, available at: http:// magazines.russ.ru/znamia/2016/6/komediya-del-arte.html

Astvatsaturov, A. (2015). Osen'v karmanakh [Autumn in the Pockets]. Moscow: Ast.

Astvatsaturov, A. (2011). Skunskamera [Skunskamera]. Moscow: Ad Marginem Press.

Astvatsaturov, A. (2010). Liudi v golom [People in the Nude]. Moscow: Ad Marginem Press.

Boym, S. (2013). Buduschee nostal'gii [The Future of Nostalgia], In: Neprikosnovennyy zapas [Emergency Ration], 89 (3), available at: http://www.nlobooks.ru/node/3725

Boym, S. (2003). Hypochondria of heart: nostalgia, history and memory, In: Nostalgia. Essays about the regret of Communis. Milano: Mondadori. 1-88.

Ganieva, A. (2010). Ne boysia novizny, a boysia pustozvonstva [Do Not Fear Novelty, Fear Idle Talk], In: Znamia, 3, 139-142.

Ivanova, N. (2002). Nostal'yaschee sobranie nabliudeniy [Nostalreal Collection of Observations]. Moscow: Raduga.

Carpi, G. (2016). Storia della letteratura russa. Dalla rivoluzione d'Ottobre a oggi [History of Russian Literature. From October Revolution up today]. Roma: Carocci.

Kovtun, N. (2016). Aktual'naia literatura v zerkale manifestov ("Moy manifest" V. Rasputina, "Uchenie EPS" V.Erofeeva i "Otritsanie traura" S. Shargunova) [Contemporary Literature Through the Mirror of Manifests ("My Manifest" by V. Rasputin, "EPS Theory" by V.Erofeev and "Denial of Mourning” by S. Shargunov), In: Literatura (RusisricaVillnensis), No. 2, 52-65. 
Lotman, Yu. (1998). Semiotika kino i problemy kinoestetiki [Semiotics of Cinema and Problems of Cinema Aesthetics], In: Ob iskusstve. St. Petersburg: Iskusstvo. 288-372.

Lotman, Yu. (1994). Vvedenie: byt i kul'tura [Introduction: Way of Life and Culture], In: Besedy o russkoy kul'ture. Byt i traditsii russkogo dvorianstva (XVIII-nachalo veka) [Russian Culture Talks. Way of Life and Customs of Russian Nobility ( $18^{\text {th }}$ - beginning of the century)]. St. Petersburg: Iskusstvo. 5-16

Martyanova, I. (2002). Kinovek russkogo texta: paradox literaturnoy kinematografichnosti [Cinema Life of Russian Text: Literary Cinematographicality Paradox]. St. Petersburg: Saga.

Cherniak, M. (2016). "Novyy realizm" sovremennoy prozy v kontexte russkogo traditsionalizma ["New Realism" of Contemporary Prose in the Context of Russian Traditionalism], In: Russkiy traditsionalizm. Istoriia, ideologiia, poetika, literaturnaia reflexiia [Russian Traditionalism. History, Ideology, Poetics, Literary Reflection], issue 7, 317-329.

Piretto, G. (2012). La vita privata degli oggetti sovietici [The private life of soviet things]. Milano: Sironi.

Salmon, L. (2015). Chronotopes of Affectivity in Literature. On melancholy, Estrangement, and reflective Nostalgia, In: Melancholic Identities, Toska and Reflective Nostalgia. Case Studies from Russian and Russian Jewish Culture. Firenze: Firenze University Press. 11-30.

Ulitskaia, L. (2015). Predislovie [Introduction], In: Zuleikha otkryvaet glaza [Zuleykha Opens Her Eyes]. Moscow: Ast.

\section{Запахи, вещи, звуки: знаки прошлого \\ в произведениях А. Аствацатурова}

Д.Маркуччи

Университет для иностранщев г. Сиень Италия, 53100, Сиена, Piazza Carlo Rosselli, 27/28

Новая волна русских писателей появилась в России на рубеже веков. Они не принадлежат однородному течению, но в их произведениях часто прослеживается возврат к традиционным формам повествования и к темам, касающимся человеческой природы. В контексте современной русской литературы значительную роль играют романы петербургского писателя Андрея Аствацатурова, в которых советское прошлое и настоящее переплетаются между собой в воспоминаниях главного героя. Большое количество описанных в произведениях писателя «вещей» являются отнюдь не простыми предметами, а, по определению Ю.М. Лотмана, именно «знаками времени». Семиотический и лингвистический анализ частей текста, в которых эти «вещи» стоят в центре внимания автора, позволяют заключить, что ностальгия у Аствачатурова совпадает с понятием С. Бойма рефлектирующей ностальгии - с тоской по навсегда утерянному аутентичному миру детства, отчасти идеализированному из-за мрачности и стерильности современности.

Ключевые слова: реставрирующая ностальгия, рефлексирующая ностальгия, советское прошлое, современная русская литература, знаки.

Научная специальность: 10.00.00 - филологические науки. 